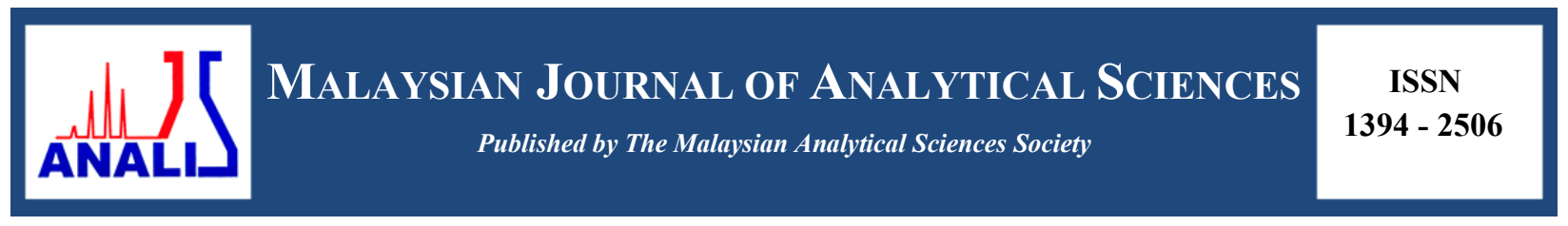

\title{
LATEX PARTICLES MORPHOLOGY OF EPOXIDISED AND HIGH AMMONIA NATURAL RUBBER LATEX FROM ELECTRON MICROSCOPY TECHNIQUES
}

\author{
(Morfologi Partikel Lateks Bagi Lateks Getah Asli Terepoksi dan Lateks Getah Asli Kandungan \\ Tinggi Ammonia daripada Teknik-Teknik Mikroskopi Elektron)
}

\author{
Norhanifah Mohd Yazid*, Fatimah Rubaizah Mohd Rasdi, Asrul Mustafa \\ Technology and Engineering Division, \\ Malaysian Rubber Board, 47000 Sungai Buloh, Selangor, Malaysia \\ *Corresponding author: norhanifah@lgm.gov.my
}

Received: 10 June 2015; Accepted: 21 July 2016

\begin{abstract}
The rubber latex particle morphology, size and also arrangements of various types of natural rubber latex are investigated in the latex state using Environmental Scanning Microscope (ESEM). Subsequently the changes in the morphology after film formation is observed using Field Emission Scanning Electron Microscopy (FESEM). Prior to film formation, in the latex state, epoxidised natural rubber showed marked differences in latex particle morphology and arrangement compared to high ammonia latex. Subsequently, after the films are formed, the microscopy results exhibited certain dissimilarities between high ammonia and epoxidised natural rubber latex films particularly particle clustering. It is revealed that the high ammonia natural rubber latex film showed distinctly larger spherical shaped latex particles at the surface of the films in contrast to the smaller latex particles as observed in the epoxidised natural rubber latex film. The present study provides insight into the differences in the film formation between high ammonia and epoxidised natural rubber latex, which may also influence the properties of the resulting rubber latex films and latex products.
\end{abstract}

Keywords: high ammonia natural rubber latex, epoxidised natural rubber latex, film formation, latex particles

\begin{abstract}
Abstrak
Morfologi partikel lateks getah, saiz dan juga susunan pelbagai jenis lateks getah asli dicirikan dalam bentuk lateks menggunakan Mikroskop Imbasan Alam Sekitar (ESEM). Selepas itu perubahan morfologi selepas pembentukan filem diperhatikan menggunakan Mikroskop Elektron Imbasan Medan (FESEM). Sebelum pembentukan filem, dalam bentuk lateks, getah asli terepoksi menunjukkan perbezaan yang ketara dalam morfologi partikel lateks dan susunan berbanding lateks getah asli ammonia kandungan tinggi. Selepas itu, setelah filem terbentuk, analisis mikroskop menunjukkan ketidaksamaan tertentu antara filem lateks getah asli kandungan tinggi ammonia dan lateks getah asli terepoksi terutamanya kelompok partikel. Ia mendedahkan bahawa filem bagi lateks getah asli kandungan tinggi ammonia menunjukkan partikel lateks berbentuk sfera jelas lebih besar di permukaan filem berbeza dengan partikel lateks yang lebih kecil sebagaimana yang berlaku di filem lateks getah asli terepoksi. Kajian ini memberi gambaran tentang perbezaan dalam pembentukan filem di antara lateks getah asli kandungan tinggi ammonia dan lateks getah asli terepoksi, yang juga boleh mempengaruhi sifat - sifat yang terhasil filem lateks getah dan produk getah.
\end{abstract}

Kata kunci: lateks getah asli kandungan tinggi ammonia, lateks getah asli terepoksi, pembentukan filem, partikel lateks 


\section{Introduction}

Natural rubber (NR) is an elastomer which has been commercially available for nearly a hundred years and it comes with unique physical and chemical properties which are suitable for tires, gloves, condoms, adhesives and etc. [1]. The application of NR in such products hinges on its ability to undergo strain-induced crystallisation which results in high tensile, tear and fatigue properties [2].

The introduction of chemical modification in NR is carried generally to improve properties, such as oil resistance in order to extend NR latex areas of application and as a new material $[2,3]$. One of the chemical modifications is epoxidation which converts NR to epoxidised NR (ENR). Through epoxidation, oxirane (epoxide) is introduced where oxygen atom is added to the unsaturated NR carbon- carbon double [4]. ENR is commercially available in two grades namely ENR-25 (25 mole \% epoxide) and ENR-50 (50 mole \% epoxide).

Even though epoxidation of NR has been started in 1922 [5], the literatures on ENR latex state is deemed inadequate. This is probably due to the application of ENR was more towards dry rubber application hence more of the research approaches are focused on dry rubber [6-10]. With regards to ENR latex state, information is still lacking especially on latex particle arrangement and film formation.

With regards to the use of microscopy to study rubber, there are research adequate works which described the use of electron microscopy to study rubber latex particle [11-13], however still much of the work utilised dry state latex thin films in their study. The investigation on latex particles morphology using ESEM in the latex or aqueous state and consequently the latex particles packing in films using FESEM has not been yet attempted so far. Hence, in this preliminary work, visualization of chemically modified NR and the subsequent film was carried out by using ESEM and FESEM. The average of latex particles also calculated in this present work.

\section{Materials and Methods}

\section{Materials}

Concentrated high ammonia natural rubber latex (HA-NRL) was purchased from Lee Rubber, Malaysia Epoxidised natural rubber (ENR 1) and epoxidised natural rubber (ENR 2) latex were obtained from Development of Specialty Rubbers and New Rubber Program, Malaysia Rubber Board with epoxidation level 25\% mole. For dilution purposes, distilled water was used throughout the study.

\section{Latex particle morphology using ESEM}

HA-NRL and ENR sample and distilled water were mixed in Eppendorf tube prior shaking for a few minutes. Then, the solution was centrifuged for 10 minutes. After that, sample was collected then osmium tetroxide was used to stain the sample. The sample was left to dry for several hours before washing and centrifugation. Then, the sample was ready for ESEM viewing. The morphology of particles was analysed using an ESEM (FEI Quanta). Then, the average of particle size was calculated using ImageJ software (NIH, Freeware).

\section{Film formation and particles packing using FESEM}

HA-NRL and ENR samples were stained with osmium tetroxide prior to FESEM analysis. The sample was then air dried in the desiccators on sample stub before coating with thin layer of platinum. Then, surface area of latex film was analysed using FESEM (JOEL JSM-6701F) at 5000 magnification.

\section{Latex particle morphology}

\section{Results and Discussion}

The ESEM micrographs in Figure 1(a, c, e) present different latexes at latex state. Figure 1a which represents HANRL particles packing showed the existence of both spherical and pear shaped latex particles similar with previous studies on NR latex $[11-12,14]$ where small particles were in spherical or egg shape and large particles were in pear shape. The latex particles were randomly distributed where agglomeration of latex particles could be observed in a close arrangement of latex particles. The large latex particles which in pear shaped were shown to be clustered by smaller latex particles. 
After epoxidation (Figure 1c), the arrangement of latex particles changed and agglomeration of particles appeared to be reduced. The latex particles were no longer closer to each other. As result to epoxidation, based on the micrographs the shape of latex particles could be observed in circular and smaller size only. The pear shaped particle could not be detected in the micrographs (Figure1c and 1e).

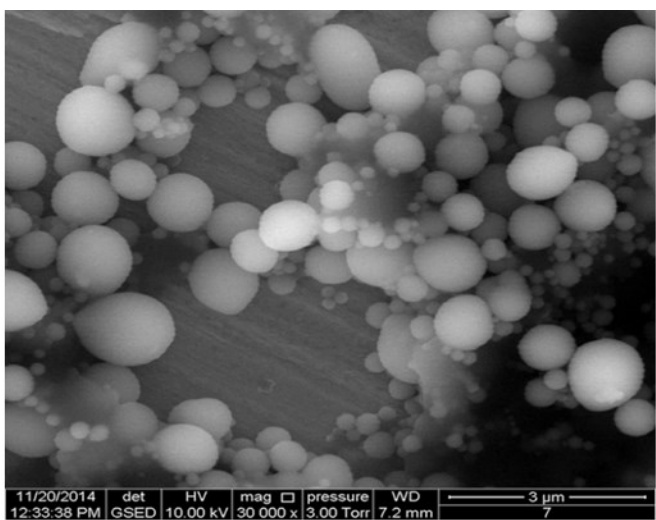

(a) HA-NRL at latex state

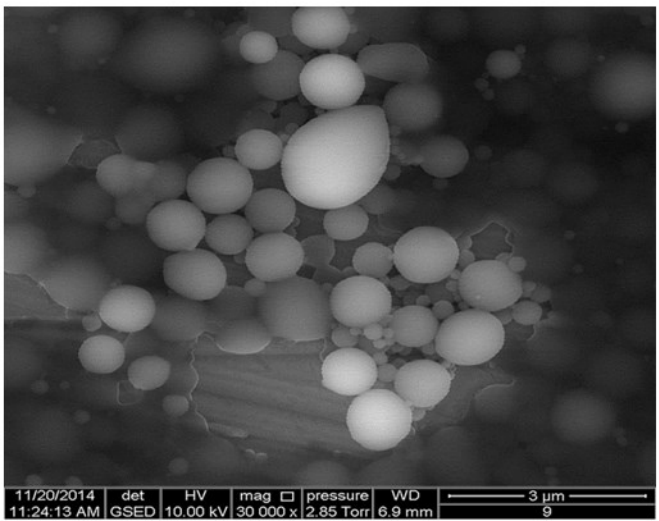

(c) ENR 1 at latex state

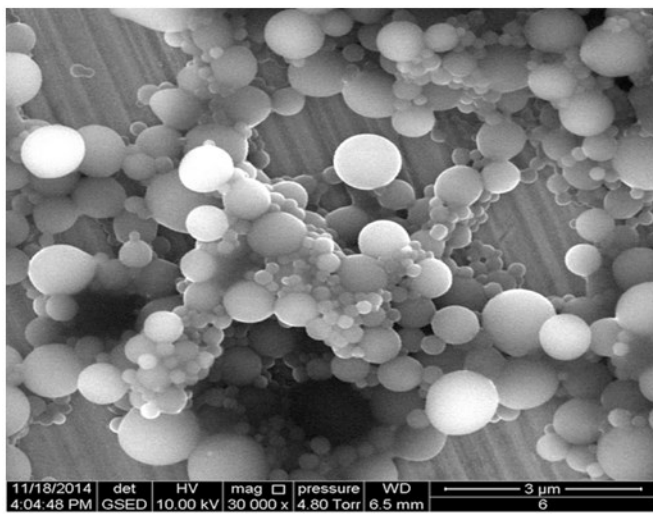

(e) ENR 2 at latex state

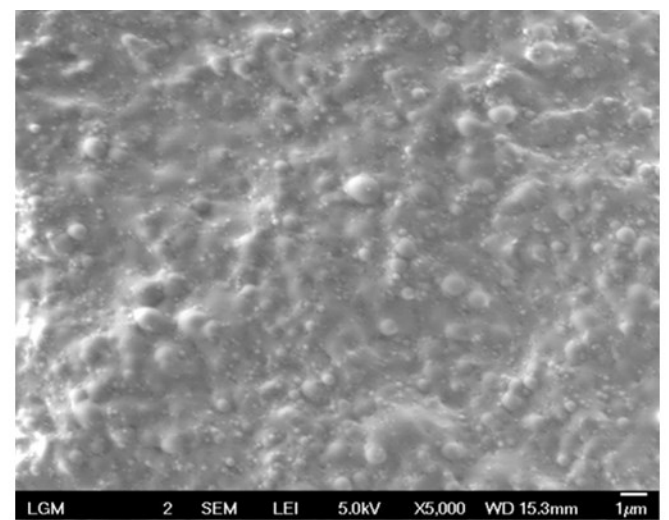

(b) HA-NRL at dry film state

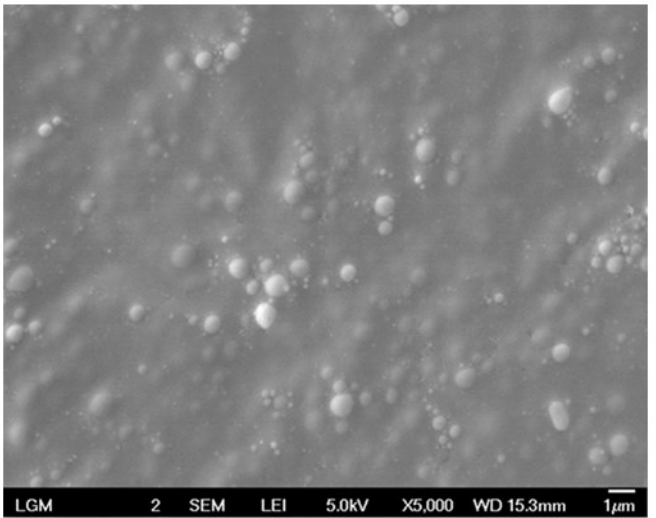

(d) ENR 1 at dry film state

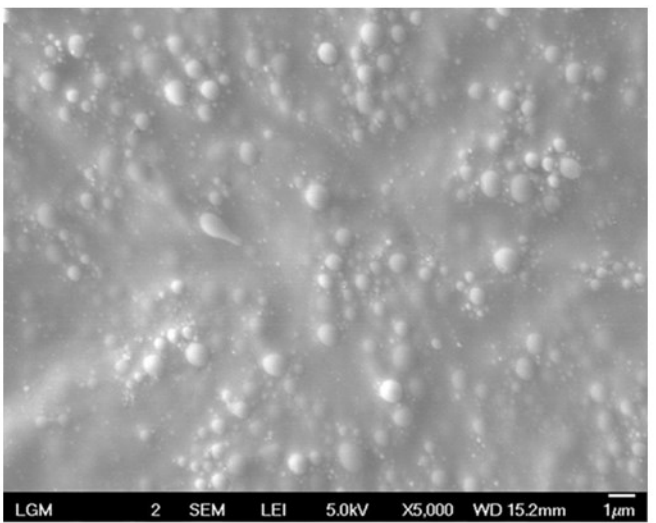

(f) ENR 2 at dry film state

Figure 1. ESEM (a, c, e) and FESEM (b, d, f) micrographs showing of different latexes at various magnification for latex and dry film state. 
Meanwhile, for Figure 1e, as could be seen the arrangement of particles was different to Figure 1c where the particles were closer to each other and clustering of smaller particles in between large particles could be seen clearly. The spherical shaped latex particles could be observed whilst the small particles were agglomerated to each other formed larger particles. The similar phenomenon also observed in this micrograph where the pear shaped latex particle could not be observed. This is because ENR 1 and ENR 2 had undergone epoxidation with different propriety processing process. Thus, this could lead to different particle arrangement as seen in the micrographs. So, based on the findings, it is suggested that epoxidation on natural rubber latex has given some effect to latex particles shape and also modified the arrangement of latex particles.

The average of latex particles in the latex state is shown in Figure 2. In the present investigation, average latex size existing in the latex state was measured from the ESEM micrographs. As per stated elsewhere [15], a particle size analysis results merely in 'average' diameter, whether based a number, surface area, volume, is of limited value. The average size of latex particles was in the range of 0.5 to $1.2 \mu \mathrm{m}$ was taken as the limiting range in this present work because ImageJ software has limitation to the smaller size of latex particles. From particle size analysis using laser diffraction the range of particle size for Hevea latex was around 0.01 to $5.0 \mu \mathrm{m}$ [16] and $0.2 \mu \mathrm{m}$ to $1.5 \mu \mathrm{m}$ [17]. Based on Figure 2, the average of particles size between all the latex samples were not much different. This is due to the limitation of measurement by using ImageJ. The results were also consistent with result of previous study [15], where the distribution of average particles size based on particles diameter exhibited higher distribution between 700 to $1500 \mathrm{~nm}$. This also explained the average of different latexes exhibited almost similar results to each other.

The average of particles size after drying process for HA-NRL and epoxidation natural rubber latex from FESEM micrographs was measured and the result shown in Figure 2. The trend of latex particles size distribution among HA-NRL, ENR 1 and ENR 2 was similar to result of ESEM micrographs. The size of latex particles after drying showed a reducing trend compared to the ESEM result. This result may have suggested that after drying process, the latex particles size could be reduced in size due to evaporation process at stage I and II which are deformation particles occurred [18].

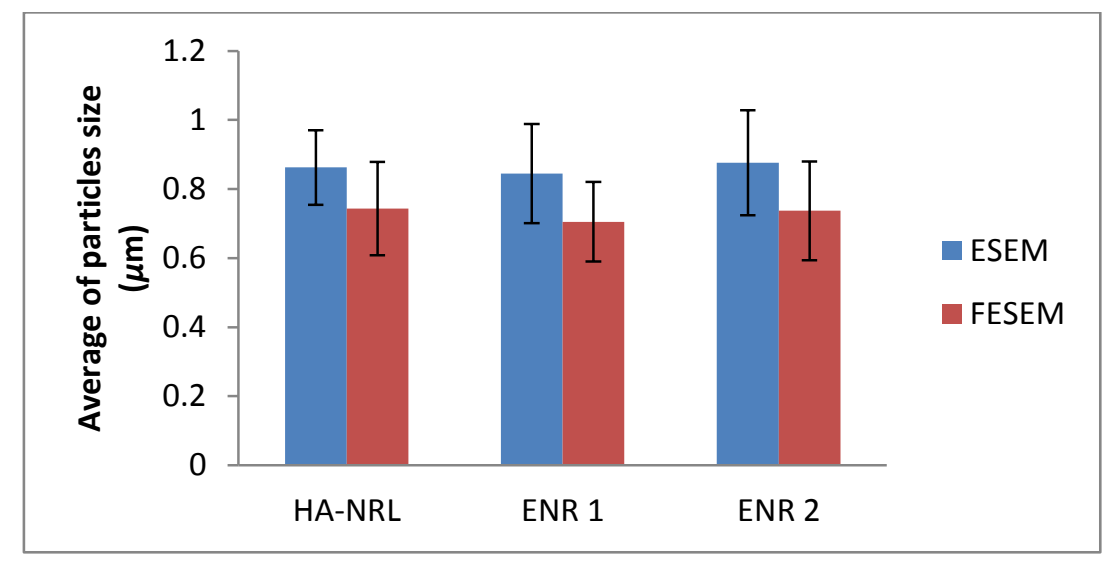

Figure 2. Average latex particles size for different latexes based at latex (ESEM) and dry state (FESEM).

\section{Film formation and particles packing}

FESEM micrographs conducted on air dried thin films obtained from HA-NRL, ENR 1 and ENR 2 latex. The features occurred on HA-NRL film were undulation with distinguished latex particles spherical shaped (Figure 1b). Clearly, the polydisperse latex particles distribution could be observed on the surface of formed HA-NRL film even though coalescence of latex particles had already occurred during drying. The core shell structure of HANRL latex particles almost diminished due to occurrences inter-particle diffusion of NR molecules. It is essential in order for 
inter-particle mixing of rubber molecules takes place to ensure complete coalescence of the particles as per seen in micrograph. In this case, suggested coalescence and film formation were occurred in same time.

After epoxidation, the surface morphology the film was shown to be in different features compared to HA-NRL latex film. Based on FESEM micrographs (Figure 1d and 1f), the undulation feature on HA-NRL latex film is no longer observable. ENR 1 films exhibited a more coherence films with less distinguishable latex particles. However, in ENR 2 (Figure 1f), clusters of spherical shaped latex particles can be seen on the film surface clearly. The packing of particles could not be observed on the surface morphology in contrast with HA-NRL. This suggested that the changes in latex particles surface morphology are dependent on the type of modification. This is consistent to the ENR 1 and ENR 2 different surface morphology due to the effect processing process. It also could be suggested that inter-particle diffusion process which lead to the coalescence of the particles could be reacted different with HA-NRL.

\section{Conclusion}

The interesting findings have been observed using combination of ESEM and FESEM techniques in relation to the elucidation of latex particles arrangement in aqueous latex state and particles packing after the drying of latex to form films. In latex state, it can be suggested that epoxidation contributed to smaller size of latex particles. Subsequently after drying and when films are formed, ENR exhibited a more coherence and less undulating surface in contrast to HA-NRL film.

\section{Acknowledgement}

Permission from the Malaysia Rubber Board to present the results is gratefully acknowledged. Thanks are due to Fine Chemicals and Biomaterials staff for technical support. The assistance from Cowen Tan and Ho Oi Kuan from Crest, Malaysia is also gratefully acknowledged

\section{References}

1. Yoksan, R. (2008). Epoxidized natural rubber for adhesive applications. Kasetstart Journal (Natural Science), 43: $325-332$.

2. Gelling, I. R. (1988). Chemistry, structure and properties epoxidised natural rubber. International Rubber Technology Conference: 415 - 427.

3. Le Bras, J. and Delalande. A. (1950). Derives Chimiques du Caouchouc Naturel, Paris, Dunod.

4. Fatimah Rubaizah, M. R, Ngeow, Y. W., Zairossani, M. N. and Md. Aris, A. (2008). ENR-37.5 as a new epoxidised natural rubber (ENR) grade. International Rubber Conference \& Exhibition: 1 - 11.

5. Pummerer, R. and Burkard, P. A. (1922). On rubber. Ber, 55: $3458-3472$.

6. Baker, C. S. L., Gelling, I. R. and Azemi, S. (1986). Epoxidised natural rubber. Journal of Natural Rubber Research, 1(2): 135 - 144.

7. Yong, K. C., Foot, P. J. S., Morgan, H., Cook, S., Tinker, A. J. and Md Aris, A. (2008). Electrically conductive epoxidised natural rubber-polyaniline dodecylbenzenesulfonate blends prepared by solution mixing. Journal of Rubber Research, 11(2): 59 - 77.

8. Haidzir, A. R., Gelling, I. R. and Freakley, P. K. (1994). Influence of phase morphology on the properties of natural rubber and epoxidised natural rubber blends. Journal of Natural Rubber Research, 9(4): 213 - 225.

9. Suhawati, I., Ismaliza I., Kamarudin A. M. and Shamsul, K. (2013). Sound absorption analysis of foamed rubber composites from kenaf and calcium carbonate. Journal of Rubber Research, 16(1): $36-44$.

10. Dayang Habibah, A. I. H., Shamsul Bahri, A. R. and Nik Intan, N. I. (2013). Morphology, physical and flame retardant properties of epoxidised natural rubber (ENR) organoclay compound. Journal of Rubber Research, 16(2): $91-100$.

11. Van Den Tempel, M. (1952). Electron microscopy of rubber globules in Hevea latex. Transaction of the Institution of the rubber industry, 28 (6): $303-309$.

12. Gomez, J. B. and Hamzah, S. (1989). Particle size distribution in Hevea latex - Some observations on the electron microscopic method. Journal of Natural Rubber Research, 4(3): $204-211$.

13. Southorn, W. A. (1960). Complex particles in Hevea latex. Nature, 188: $165-166$.

14. Hauser, E. A. (1946). The morphology of rubber latex particles. A critical review. India Rubber World, 112(4): $461-463$. 
Norhanifah et al: LATEX PARTICLES MORPHOLOGY OF EPOXIDISED AND HIGH AMMONIA NATURAL RUBBER LATEX FROM ELECTRON MICROSCOPY TECHNIQUES

15. Gorton, A. D. T and Pendle, T. D. (1983). Particle size measurement of rubber latices. Rubber Chemistry and Technology, 56: $664-676$.

16. Gazaley, K. F., Gorton, A. D. T. and Pendle, T. D. (1988). In latex concentrate: Properties and composition, Roberts, A.D (ed), Rubber Science and Technology, Chapter 3. Oxford University Press: $63-90$.

17. Pendle, T. D. and Swinyard, P. E. (1991). The particle size of natural rubber latex concentrates by photon correlation spectroscopy. Journal of Natural Rubber Research 6 (1): 1 - 11.

18. Keddie, J. L. and Routh, A. F. (2010). In Fundamental of latex film formation; Process and properties. Parch, H. Chapter 1. Springer: $10-18$. 